Land Degradation \& Development

\title{
THE DECLINE OF THE LAKE TANA (ETHIOPIA) FISHERIES: CAUSES AND POSSIBLE SOLUTIONS
}

\begin{tabular}{|r|l|}
\hline Journal: & Land Degradation \& Development \\
\hline Manuscript ID & LDD-16-0243.R4 \\
\hline Watey - Manuscript type: & Special Issue Article \\
\hline Complete List of Authors: & $\begin{array}{l}\text { Dejen, Eshete; 1Intergovernmental Authority on Development, Agriculture } \\
\text { and Environment Division } \\
\text { Anteneh, Wassie; Bahir Dar University, Biology } \\
\text { Vijverberg, Jacobus; Netherlands Institute of Ecology (NIOO-KNAW), } \\
\text { Department of Aquatic Ecology }\end{array}$ \\
\hline Keywords: & $\begin{array}{l}\text { land use, biosphere reserve, maximum sustainable yield, Nile tilapia, } \\
\text { Labeobarbus }\end{array}$ \\
\hline
\end{tabular}




\title{
THE DECLINE OF THE LAKE TANA (ETHIOPIA) FISHERIES: CAUSES AND POSSIBLE SOLUTIONS
}

\author{
Eshete Dejen $^{1}$, Wassie Anteneh ${ }^{2 *}$ Jacobus Vijverberg $^{3}$ \\ ${ }^{1}$ Intergovernmental Authority on Development, P. O. Box, 2653, Djibouti \\ ${ }^{2}$ Bahir Dar University, College of Science, Department of Biology, P.O. Box 79, Bahir Dar, \\ Ethiopia,wassie74@gmail.com \\ ${ }^{3}$ Netherlands Institute of Ecology (NIOO-KNAW), Department of Aquatic Ecology, P. O. Box \\ 50, 6700 AB Wageningen, the Netherlands \\ *Corresponding author
}

Short title: DECLINE OF LAKE TANA FISHERIES: CAUSES AND SOLUTIONS 


\begin{abstract}
This article reviews major findings of a vast body of scientific studies on the ecology of the fish community and the fisheries in Lake Tana over the past 25 years. There are three commercially important fish taxa in the lake: Nile tilapia, African catfish and Labeobarbus spp. The catch per unit of effort for all the three taxa declined during the last two decades: total catch $177 \mathrm{~kg} / \mathrm{trip}$ in $1993,140 \mathrm{~kg} /$ trip in 2001 and $56 \mathrm{~kg} /$ trip in 2010. But the most drastic reduction was observed for the Labeobarbus species: $63 \mathrm{~kg} /$ trip in 1993, $28 \mathrm{~kg} /$ trip in 2001 and only $6 \mathrm{~kg} /$ trip in 2010 . Most probably, both recruitment overfishing and increased recession farming contributed to the decline. The migrating Labeobarbus spp. were heavily affected by irrigation and dam constructions causing destruction of breeding and nursery habitats in the spawning rivers. We conclude that implementation of the fisheries legislation gazetted in 2003 and the lake management plan adopted in 2015 is crucial to prevent the collapse of the Lake Tana fishery. Suspended silt from erosion and land degradation, caused by deforestation in the catchment, increased the turbidity of the lake water. The current Maximum Sustainable Yield is approximately $10-20 \mathrm{~kg} \mathrm{ha}^{-1} \cdot \mathrm{yr}^{-1}$, which is low compared to other African lakes. The low productivity seems to be caused both by both light limitation and nutrient limitation. Soil erosion is probably limiting primary production. Appropriate land use management and soil conservation around Lake Tana, such as afforestation and implementing zero-grazing practices, are urgently needed.
\end{abstract}

KEYWORDS: land use; biosphere reserve; maximum sustainable yield; Nile tilapia; Labeobarbus 


\section{INTRODUCTION}

Until recently, fish was not highly valued by Ethiopians as a source of animal protein. Before 1980s the average per capita annual fish consumption by Ethiopians was only $0.1 \mathrm{~kg}$ (de Graaf, 2003). As a result the fishery in Ethiopia is one of the poorest developed sectors of the economy. Prior to mid 1980s, the fisheries in Lake Tana consisted of predominantly subsistence reed boat fishery, operated by the Negada-Woito ethnic group. Absence of motorized boats restricted the fishers' mobility to the shore areas of the lake. The fishers used locally made fish traps, hooks and small gillnets $(15-20 \mathrm{~m}, 8-10 \mathrm{~cm}$ stretched mesh), mainly targeting Nile tilapia (de Graaf et al., 2006). Modern fishing gears, such as motorized boats and nylon twine gillnets, were introduced in 1986 by the Lake Tana Fisheries Resources Development Program. This project was launched by the Dutch Non Governmental Organization (NGO), Interchurch Foundation Ethiopia, (ISE-Urk), to assist the poor fishers around the Southern Gulf area and on the nearby Islands by improving fishing technologies and supplying modern fishing gears (Nagelkerke, 1997; Wudneh, 1998). This enabled the fishers to exploit offshore and distant river mouths in the north-eastern part of the lake, which resulted in an increase of fish catches. Furthermore, in order to improve storage and marketing facilities, the Fish Production and Marketing Enterprise (FPME) was established in Bahir Dar Town. Almost all the fish catch landed in the Bahir Dar area is purchased, processed and transported to Addis Ababa by the FPME (de Graaf et al., 2006). The three main species groups targeted by current fisheries are a species flock of endemic large Labeobarbus spp., Clarias gariepinus Burchell (African catfish) and Oreochromis niloticus Linnaeus (Nile tilapia).

From the three taxa targeted by the fishers, the endemic Labeobarbus spp. are the most vulnerable to fisheries because of their annual migration from the lake to the tributary rivers for 
spawning. The commercial gillnet fishery on Labeobarbus spp. is highly seasonal and mainly targets the spawning aggregations. More than $50 \%$ of the annual catch is obtained in the river mouths during August and September (Nagelkerke et al., 1995; Wudneh, 1998, de Graaf et al., 2005; de Graaf et al., 2006). The strong decline in the proportion of juvenile fish of the riverine spawning labeobarbs is most likely partially the result of this practice (de Graaf et al., 2004; de Graaf et al., 2006).

Deforestation, especially in the second half of the previous century, resulted in erosion and land degradation in the lake catchment area (Mekonnen et al., 2015) and there is an urgent need to solve the high soil erosion rates (Gessesse et al., 2016). Inflowing rivers carry heavy loads of suspended silt into the lake, thereby increasing the turbidity of the lake water and reducing the primary production (Wondie et al., 2007). Since phytoplankton production is the basis of the food web, this most likely also affected the higher tropic levels, and thus the fish production.

The catch per unit effort for all the three fish taxa of commercial interest declined during the last two decades, but the most drastic reduction was observed for the Labeobarbus species. In this review we focus on the potential reasons of this decline and investigate to what extent management options and legislations may mitigate the present poor state of the fisheries in Lake Tana.

This review summarizes the most important results of fisheries and fish ecological studies on Lake Tana of the past 25 years. Employing a holistic view, it also explores the underlying factors affecting its productivity. This review is mainly based on published scientific papers from cooperative studies carried out by researchers from Wageningen University (Netherlands), Bahir Dar University (Ethiopia), Addis Ababa University (Ethiopia) and the Amhara Region 
Agricultural Research Institute (ARARI). We have structured the review as follows: study area, primary productivity and carrying capacity for fish harvest, fish-food organisms, fish community, fisheries, threats to the fisheries, and fisheries management and legislation.

\section{RESULTS}

\section{Study Area}

Lake Tana is situated in the north-western highlands of Ethiopia $\left(12^{\circ} \mathrm{N}, 37^{\circ} 15^{\prime} \mathrm{E}\right)$ on a basaltic plateau at an altitude of $1830 \mathrm{~m}$ and covers an area of ca. $3050 \mathrm{~km}^{2}$. It is the source of the Blue Nile River (Great Abbay), with a catchment area of ca. $16500 \mathrm{~km}^{2}$. Seven permanent and more than 40 small seasonal rivers feed the lake with water. The Blue Nile is the only outflowing river.

The climate of Lake Tana is characterised by four seasons: A main-rainy season with heavy rains during July-September, a post-rainy season during October-November, a dry season during December-April and a pre-rainy season during May-June. In the lake, dissolved oxygen concentration (range: $6.4-7.2 \mathrm{mg} \mathrm{l}^{-1}$ ) and temperature (range: $22.5-23.5{ }^{\circ} \mathrm{C}$ ) vary seasonally only within narrow limits. Conductivity was lowest in the main-rainy season (average: $142 \mu \mathrm{S} \mathrm{cm}^{-1}$ ) and highest in dry and pre-rainy seasons (average: 182-184 $\mu \mathrm{S} \mathrm{cm}^{-1}$ ); range calculated over a 20 months period (Wondie et al., 2007).

Lake Tana is shallow (average depth $8 \mathrm{~m}$, maximum depth $14 \mathrm{~m}$ ) and oligotrophicmesotrophic. Its water column does not experience any lengthy period of thermal stratification 
(Dejen et al., 2004). Annual soil loss in the Lake Tana catchment is high (Shimelis et al., 2009).

Inflowing rivers carry a heavy silt load into the lake during the rainy season. The suspended sediments reduce the underwater light intensity and as such the primary production of Lake Tana (Wondie et al., 2007).

Bahir Dar, located on the southern border of the lake, is a Regional capital with ca. 260 000 inhabitants. Around the lake and its catchment, including the town of Bahir Dar, live about two million people. The area around the lake has been cultivated for centuries. This lake and adjacent wetlands provide directly and indirectly a livelihood for more than 500000 people.

Extensive wetlands, of which Fogera and Dembia floodplains are the largest, jointly comprise ca. $65 \%$ of the lake's catchment area (Figure 1). These wetlands are the largest in the country and form an integral part of the complex Tana-ecosystem. During the rainy period these wetlands are hydrologically connected with the lake. They act as nurseries for most fish populations in the lake, and serve as breeding ground for water fowl and mammals. The diversity of birds is especially high (Atnafu et al., 2011).

\section{Primary Production and Carrying Capacity for Sustainable Fish Harvest}

The lake is characterised by a low water transparency due to high silt load of the inflowing rivers during the rainy seasons (May-November) and daily resuspension of sediments in the inshore zone. Earlier studies found no relation between chlorophyll-a content and water transparency, which might suggest that water transparency is mainly controlled by suspended sediments rather than by phytoplankton biomass. The mean chlorophyll-a concentration varied seasonally and ranged from 2.6-8.5 $\mathrm{mg} \mathrm{m}^{-3}$ (mean: $4.5 \mathrm{mg} \mathrm{m}^{-3}$ ) in the offshore zone (Wondie et al., 2007). 
Measurements of primary productivity during different seasons over two years indicate that the gross primary production in the open water in Lake Tana was relatively low (Wondie et al., 2007). The highest production rates were observed in the post-rainy season (Oct -Nov) which coincided with a bloom of Microcystis and higher chlorophyll-a levels. This seasonal high production is very likely caused by the sediment run-offs in the rainy season resulting in higher nutrient inputs. It is also the season in which the water is most turbid due to extensive sediment run-off during the rains and might be an indication for light limitation. These conditions favoured Microcystis spp. (Cyanobacteria) which through its buoyancy have an advantage over other algae (Wondie et al., 2007).

The gross primary production rates of Lake Tana are among the lowest compared with other tropical lakes (Wondie et al., 2007). The relationship between sediment concentration, water transparency and nutrient availability is complicated. In general, the two main reasons for the lower productivities in turbid waters are the absorption of nutrients on the suspended clay particles, making them less available for phytoplankton, and the reduction of the depth of the euphotic zone (Grobbelaar, 1983). Therefore, suspended silt can have both a direct and an indirect negative effect on the primary production. Thus although primary production in Lake Tana seems to be limited by nutrient availability, the elevated sediment concentration might also an important limiting factor.

A rough estimate of the total maximum sustainable fish yield (MSY) was made based on estimates of the gross primary production in the open water of Lake Tana (average $2.4 \mathrm{~g} \mathrm{O}_{2} \mathrm{~m}^{-2}$ ), using the predictive regression model given by Melack (1976) for nine African lakes (for more information about this approach see Downing et al., 1990). On basis of the average primary production the estimated possible yield would be ca. $10 \mathrm{~kg} \cdot \mathrm{ha}^{-1} \cdot \mathrm{yr}^{-1}$. However, the real MSY will 
probably be lower. Firstly, because ca. $80 \%$ of the total annual fish production (ca. $27 \mathrm{~kg} \cdot \mathrm{ha}^{-1} \cdot \mathrm{yr}^{-}$ ${ }^{1}$ ), is represented by two Barbus spp. that are not utilized by the fisheries (Wudneh, 1998; Dejen et al., 2006; Dejen et al., 2009).

Secondly, independent estimate of MSY can be made based on the total fish production. The total fish production in the lake was estimated to be $93 \mathrm{~kg}$ wet weight $\mathrm{ha}^{-1} \mathrm{yr}^{-1}$ of which 53 kg wet weight $\mathrm{ha}^{-1} \mathrm{yr}^{-1}$ was realised by the two Barbus spp. (Wudneh, 1998; Dejen et al., 2009). The MSY for the whole fish community was estimated on the basis of this production estimate using the equation given by Sparre \& Venema (1998). MSY for the whole fish community was estimated to be $18.6 \mathrm{~kg}$ wet weight $\mathrm{ha}^{-1} \mathrm{yr}^{-1}$ of which $10.6 \mathrm{~kg}$ wet weight $\mathrm{ha}^{-1} \mathrm{yr}^{-1}$ was the potential MSY of the two Barbus spp. Therefore, on basis of the fish production the estimated MSY for the whole fish community of Lake Tana is approximately $20 \mathrm{~kg} \cdot \mathrm{ha}^{-1} \cdot \mathrm{yr}^{-1}$, but this estimates also includes the small barbs, which are currently not targeted by the fishery. If we exclude the Barbus spp. the estimated MSY is ca. $10 \mathrm{~kg} \cdot \mathrm{ha}^{-1} \cdot \mathrm{yr}^{-1}$ which is low compared to other African lakes (Melack, 1976; Jul-Larson et al., 2003).

\section{Fish-food organisms}

Zooplankton organisms are the dominant secondary producers in Lake Tana (Dejen et al., 2004). Approximately half of the numbers encountered were copepods and the other half cladocerans. The calanoid copepod Thermodiaptomus galebi lacustris, which is endemic to the Lake Tana catchment, dominated the zooplankton community. Of the cladocerans two daphnia species, Daphnia hyalina and D. lumholtzi are common. 
The zooplankton community structure of Lake Tana is unusual for tropical lakes because of its relatively high proportion of temperate species, i.e. D. hyalina, and Ceriodaphnia dubia (Dejen et al., 2004). This can likely be attributed to the relatively low water temperatures of Lake Tana due to its high altitude. Significant temporal differences in copepod and cladoceran abundance were observed, with the highest overall zooplankton density in the dry season (Dejen et al., 2004).

Macrobenthic invertebrates such as oligochaetes, Chaoborus spp. and chironomids, show low densities both inshore and offshore (Jacobus Vijverberg, unpublished). In contrast the microbenthic ostracods show relatively high densities in the inshore zone (4 000-60 $\left.000 \mathrm{ind} \mathrm{m}^{-2}\right)$, but are lacking in the offshore area of the lake. The low densities of benthic invertebrates may be caused by the low content of organic matter in the bottom substrates, which consists of volcanic basalts usually covered with a soft substratum transported by the inflowing rivers. Density and biomass of macrofauna in the macrophyte beds are relatively high, but these beds are limited to the littoral zone (ca. 10\% of lake surface area).

\section{Fish Community}

Twenty one of the 28 fish species in Lake Tana are endemic to the Lake Tana catchment (Table I). This speciation could occur because the lake maintained its isolation from the lower Blue Nile basin by $40 \mathrm{~m}$ high falls, $30 \mathrm{~km}$ downstream from the Blue Nile outflow (Sibbing et al., 1998). Although the lake was formed ca. 5 million years ago by lava blocking of the Blue Nile, the lake dried up several times. The last drying event occurred 10 000-15 000 years ago, thus the endemic fish species are not older than 15000 years (Lamb et al., 2007). 
The most species-rich fish family in the lake are the cyprinids, represented by four genera: Barbus, Garra, Labeobarbus and Varicorhinus. The genus Garra is represented by four species, G. dembecha Getahun and Stiassny, G. dembeensis (Rüppell) and two endemic species, G. regressus Getahun and Stiassny and G. tana Getahun and Stiassny (Stiassny\& Getahun, 2007). All four species are algivorous. Varicorhinus is represented by a single species $V$. beso Rüppell which scrapes algae from substrates.

Fifteen large (max. $82 \mathrm{~cm}$ fork length, FL) labeobarbs (Labeobarbus spp.) belong to a unique species flock of endemic cyprinids (Nagelkerke et al., 1994; Nagelkerke \& Sibbing, 2000; Nagelkerke et al., 2015). The cyprinid fish community also contains, furthermore, three small $(<11 \mathrm{~cm}$ FL) barbs: Barbus humilis Boulenger, B. pleurogramma Boulenger and $B$. tanapelagius de Graaf, Dejen, Sibbing \& Osse (Boulenger) (de Graaf et al., 2000). The latter two species are endemic to the Lake Tana catchment. Barbus humilis is mainly present in the shallow inshore zone, whereas B. tanapelagius is common in the large pelagic zone of the lake. Barbus pleurogramma is mainly present in the wetlands around the lake.The three Barbus spp., feed on zooplankton (Dejen et al., 2006; Vijverberg et al., 2014), with B. tanapelagius being the only obligate zooplanktivore since the other species utilise also other animal food items. Barbus pleurogramma maintains the most benthivorous diet, whereas B. humilis, juvenile labeobarbs and Labeobarbus brevicephalus (Nagelkerke \& Sibbing) feed for ca. half (by biovolume) of their diet on zooplankton and for the other half on adult floating insects, insect larvae and benthic invertebrates. Barbus tanapelagius and the adults of L. Brevicephalus are the only zooplanktivores occupying the large offshore zone (Dejen et al., 2006).

Several studies showed that nine Labeobarbus species, L. acutirostris (Bini), L. brevicephalus, L. intermedius (Rüppell), L. macrophtalmus (Bini), L. megastoma (Nagelkerke \& 
Sibbing), L. nedgia (Rüppell), L. platydorsus (Nagelkerke \& Sibbing), L. truttiformis (Nagelkerke \& Sibbing) and L. tsanensis (Nagelkerke \& Sibbing), ascend more than $50 \mathrm{~km}$ up tributary rivers for reproduction during the main rainy season. They spawn in fast flowing, clear, well oxygenated gravel beds of the tributary streams (reviewed by Anteneh et al., 2012a). Age $0+$ juveniles of the migratory riverine spawning Labeobarbus species stay in the pools of the rivers near the spawning area until the following rainy season (Anteneh et al., 2013a).

There is only one cichlid, O. niloticus (Nile tilapia), which is predominantly an herbivore, feeding on macrophytes, algae and detritus. The catfish family (Clariidae) is represented by a single species, C. gariepinus (African catfish). This species is an omnivore, feeding mainly on zooplankton (Vijverberg et al., 2014).

Fish diet studies based on gut content analyses collected during multiple months over two years show that most fish species relied directly or indirectly on zooplankton (Nagelkerke, 1997; de Graaf et al., 2003; Dejen et al., 2006). The zooplankton production was estimated from calculated biomass and published annual $\mathrm{P} / \mathrm{B}$ ratios (accumulated production over 12 months divided by the average biomass over the same period). Assuming a 10\% trophic efficiency, and a dry: fresh weight ratio of 1:5 for fish, this resulted in an estimated potential zooplanktivorous fish production of $185 \mathrm{~kg} \mathrm{ha}^{-1}$ year ${ }^{-1}$. Since the total small barb production was estimated to be only $52.9 \mathrm{~kg}$ fresh wt ha ${ }^{-1}$ year $^{-1}$, this means that Barbus spp. only consume a small proportion (about 29\%) of the total zooplankton production (Dejen et al., 2009). They are not utilizing calanoid copepods, which represent ca. $57 \%$ of the zooplankton production and it is likely that because of this the Barbus production was food limited (Dejen et al., 2009). It is estimated that piscivorous labeobarbs consumed about $56 \%$ of the Barbus production annually. But additionally 
many bird species were also preying on them (Nagelkerke, 1997). Therefore, limitation of Barbus production by predation during certain periods in the year is likely.

Eight species of the fifteen endemic Labeobarbus species are piscivorous, four are obligate piscivorous and four others are facultative piscivores (Sibbing \& Nagelkerke, 2001; de Graaf et al., 2003). The main prey items eaten and matching their optimal prey size were $B$. humilis (40\% of the gut contents), B. tanapelagius (32\%) and Garra species (21\%). Therefore, the two small barbs form the main link between the zooplankton and the piscivorous fish in the food web of the lake.

\section{The Fisheries}

Currently, there are both reed boat and motorised gillnet fishery in Lake Tana. About $80 \%$ of the fishers use reed boats and the remaining 20\% have motorized boats for fishing (Gebremedhin et al., 2013). In order to compensate the declining commercial catch, the fishers sharply increased their fishing effort. The number of motorized boats increased from 5 in 2000 to 80 in 2010 (Mohammed et al., 2013), and the number of reed boats from 400 in 2000 to 1500 in 2010 (de Graaf et al., 2004; Mohammed et al., 2013). Before 2000, fishers had been using multifilament gillnets, but the much more efficient monofilament gillnets are currently used most often. The total number of gillnets used increased steeply, in $2011 \mathrm{ca} .20$ times more gillnets were set than in 2001 (Mohammed et al., 2013; Gebremedhin et al., 2013).

It is difficult to estimate the total fish catch for the whole of Lake Tana because of the many fish landing places around the lake. Therefore, we present here only the annual trends in catch per unit effort (CPUE). We defined the CPUE as the total daily catch in $\mathrm{kg}$ per motorized 
boat. In order to reduce bias the daily catch was standardized for the average number of gillnets carried per trip (22.21 gill nets). Total fish catch per unit effort was $177 \mathrm{~kg} /$ trip in 1993,140 $\mathrm{kg} /$ trip in 2001 and $56 \mathrm{~kg} /$ trip in 2010. The catch per unit effort for all the three commercially important fish taxa declined during the last two decades, but the decline was most severe for the endemic Labeobarbus spp. flock and African catfish (Table II). The average catch per unit effort for the endemic Labeobarbus spp. flock was $62 \mathrm{~kg} /$ trip in 1993, $28 \mathrm{~kg} /$ trip in 2001 and $6 \mathrm{~kg} /$ trip in 2010. Catch per unit effort for African catfish was $67 \mathrm{~kg} /$ trip in 1993, $36 \mathrm{~kg} /$ trip in 2001 and 8 $\mathrm{kg} / \mathrm{trip}$ in 2010 .

Threats to the Fisheries

\section{Lake siltation due to extensive deforestation}

Land degradation due to severe deforestation and land erosion in the Lake Tana catchment area has increased dramatically, especially in the second half of last century (Genet, 2011). Due to scanty vegetation and high rainfall during short periods in the main rainy season, the soil loss rate from areas around the lake is high (30-65 tonnes $\left.\mathrm{ha}^{-1} \mathrm{yr}^{-1}\right)$ and substantially increased during recent years. Soil loss rates are especially high in the eastern part of the lake, i.e. 5-250 tonnes $\mathrm{ha}^{-1} \mathrm{yr}^{-1}$, and lowest on the western side of the lake (Shimelis et al., 2001; Teshale, 2003). In the main rainy season (July-August) the four major inflowing rivers carry heavy loads of suspended 
silt into the lake, thereby increasing the turbidity of the lake water which may have a negative effect on lake productivity (Wondie et al., 2007).

\section{Changes in agricultural practices}

Recently, a shift in farming practices took place in the highlands of Ethiopia. In the earlier centuries farming occupied upland of the mountain areas, but in the last two decades with increasing population pressure and limitation of land and water, farming moved to wetlands including shorelines of lakes and river banks (Atnafu et al., 2011). This was also the case in the Lake Tana catchment (Wondie, 2010). When the lake level drops during the dry season hundreds of $\mathrm{km}^{2}$ of dry lake area becomes available for agriculture and is used by farmers to grow crops. The wetlands around the southern Bay of Bahir Dar alone cover ca. $1170 \mathrm{~km}^{2}$. These wetlands have water for ca. 4 months and it is the country's largest rice production area. Farming practices, such as, drainage and water diversions for small irrigations resulted in soil erosion and loss of soil fertility (Yitaferu et al., 2004). Socio-economic studies showed that Fogera land owners adjoining the wetlands follow the water retreat and farm until the land dries up completely (Atnafu et al., 2011). Farmers often cultivate the shore area of the lake by deforesting even to the extent of burning macrophytes (Wondie, 2010). This results in loss of spawning grounds for the fish inhabiting the lake.

Because of water abstraction for irrigation, in many tributary rivers of Lake Tana the pools became disconnected during April and May, which has severe consequences for the downstream migration of $0+$ juveniles of Labeobarbus spp. to the lake (Anteneh et al., 2013a). 
In addition, also a decline in juvenile labeobarb abundance in the pool habitats of Gumara River, a major tributary of Lake Tana, has been recorded after the river was disconnected from the lake due to excessive water abstraction from the river for small scale irrigation (Anteneh et al., 2013a). This suggests high juvenile mortality caused by desiccation of pools. Unsustainable farming of the riparian areas of the inflowing rivers has become very common in the Lake Tana region (Atnafu et al., 2011).

\section{Dam Construction}

The Ethiopian government considers the Lake Tana region to have a high potential for economic growth, mainly because of its important water resources. Mega hydropower and irrigation dam construction projects are underway in almost all tributary rivers of Lake Tana (Figure 1). It is expected that these dams will further impede the migratory riverine spawning of Labeobarbus species (Anteneh et al., 2013b). Moreover, these dams will result in a reduction of water flow in the downstream adjacent floodplains causing insufficient inundation of downstream spawning areas of African catfish and Nile tilapia (Getahun et al., 2008; Anteneh et al., 2012b).

\section{Illegal fishing gear}

Currently, almost all fishers use undersized $(5$ to $7 \mathrm{~cm})$ stretched mesh size monofilament gillnets (Tewabe, 2013). This illegal fishing gear was introduced from 2008 onwards from Sudan. The fishers strongly prefer monofilament to multifilament gillnets since they are twice to four times as efficient as multifilament nets (Faife, 2003). 


\section{Water Hyacinth infestation}

The shore macrohabitats of Lake Tana became infested by water hyacinth (Eichhornia crassipes) since 2011. This noxious weed expanded quickly after its introduction to the northern, northeastern and north-western shores of the lake and covered more than $40 \mathrm{~km}$ of the shoreline after less than two years. Currently, the water hyacinth vegetation covers ca. 34500 ha which corresponds to more than one-third of the shoreline (ca. $128 \mathrm{~km}$ ) (Anteneh et al., 2014; Anteneh et al., 2015) (Figure 2). Preliminary studies show that juvenile fishes prefer shores covered by indigenous macrophytes and avoid water hyacinth infested areas (Anteneh et al., 2015). Water hyacinth has also impacted the surrounding human communities around the lake and its catchment by reducing fish catches and decreasing available landing sites (Wassie Anteneh personal observations).

\section{Fisheries Management and Legislation}

The Federal Fish Resource Development and Utilization Proclamation 315/2003 is the legal framework for fisheries management in Ethiopia (Federal Democratic Republic of Ethiopia, 2003). The proclamation is intended to conserve fish biodiversity and its environment as well as to prevent and control over-exploitation of the fisheries resources. It includes management measures in the catchment to protect the fisheries.

The Amhara Region was the first region to develop a Regional Fisheries Proclamation (ANRS, 2003). Detailed enforcement proclamation was adopted by the regional government, the Amhara National Regional State Fisheries Resource Development Protection and Utilization Proclamation Enforcement in 2007 (ANRS, 2007). The Bureau of Agriculture is given legal 
responsibility to issue directives necessary for the full implementation of the proclamation and regulation. The Bureau has completed drafts of two directives (BoA, 2010a, b), but so far these have not been implemented. The regional government is highly concerned by the decline of the fish stock and also fishers have been asking the government to take measures. Accordingly, a team of experts was assigned to develop the Lake Tana fisheries management plan including enforcement of the proclamations.

\section{Fisheries management plan}

The Fisheries Management Plan for Lake Tana has been developed and adopted by the local government on September 2015 (Dejen et al., 2015). The management plan includes among others the implementation of the following points: issue of directives, licensing of commercial fishers, closed seasons and areas, gear restrictions, mesh size regulations, training of fisheries inspectors, and setting up a data collection and monitoring system. The Bureau of Agriculture (BoA) should issue the two directives as soon as possible. Any commercial fishing unit, such as boats, should be licensed. A license commits the fishers to respect the fishery regulations and fishery inspectors should control if the fishers obey these regulations.

To promote fish recruitment, it is important to reduce the fishing pressure on the breeding populations. To achieve this, fishing in the inflowing rivers of Lake Tana and five $\mathrm{km}$ of the river mouths will be closed for fishing every year from July to October. Wetlands around Lake Tana like Welala and Shesher will be closed from any fishing activities during the rainy season. The whole Lake Tana will be closed every year for any fishing activities for two months (June and July). Destructive fishing such as poisoning, explosives, fishing practices that can hinder the free movement of spawning stocks on spawning migrations such as fencing the rivers, seines, 
monofilament and trawls will be forbidden. Mesh size (stretched mesh) of gill nets for fishing will be limited to $8 \mathrm{~cm}$ and above, allowing immature fish to escape.

Currently, there is no standard data collection and monitoring system available. Many reports are contradicting and questionable. In the management plan detailed data collection, reporting and monitoring systems are outlined.

\section{CONCLUSIONS}

The Maximum Sustainable Yield (MSY) for Lake Tana is approximately $10-20 \mathrm{~kg} \cdot \mathrm{ha}^{-1} \cdot \mathrm{yr}^{-1}$, which is low compared to other African lakes. The low productivity seems to be caused both by light limitation and nutrient limitation. Soil erosion is probably limiting primary production and this problem will become even more important in the future where the degree of soil erosion is increasing at an alarming rate. Appropriate land use management and soil conservation around Lake Tana, such as afforestation and implementing zero-grazing practices, are urgently needed. During the last two decades the total catch per unit of effort for Labeobarbus spp. was reduced to ca. $10 \%$. This decline was mainly the combined result of recruitment overfishing, the use of illegal fishing gear and the destruction of breeding and nursery habitats in the spawning rivers by dam constructions and irrigation schemes. To prevent the collapse of the Lake Tana fishery it is crucial that the existing legislation and management plan is enforced and adopted by the local government and that management measures in the Lake Tana catchment are implemented to prevent further degradation of the Lake Tana fisheries. 


\section{ACKNOWLEDGEMENTS}

This review paper is the result of cooperative studies carried out during the last 25 years by researchers from Wageningen University (Netherlands), Bahir Dar University, Addis Ababa University and the Amhara Region Agricultural Research Institute (ARARI). ARARI has been instrumental in facilitating most of the research projects on the fisheries of Lake Tana. Most of the researches on the fishes of Lake Tana were funded by the Netherlands Foundation for the Advancement of Tropical Research, NWO-WOTRO, Critical Ecosystem Partnership Fund (CEPF) and International Foundation for Science (IFS). We thank one anonymous reviewer for many useful suggestions which improved the manuscript considerable.

\section{REFERENCES}

ANRS (Amhara National Regional State). 2003. The Determination of the Amhara National Regional State Fisheries Development, Protection and Utilization Proclamation No. 92/2003. Amhara National Regional Government, Bahir Dar, Ethiopia.

ANRS (Amhara National Regional State). 2007. The Fisheries Resource Development, Protection and Utilization Proclamation Enforcement, Council of Regional Government Regulation No. 50/2007. Amhara National Regional Government, Bahir Dar, Ethiopia. Anteneh W, Getahun A, Dejen E, Sibbing, FA, Nagelkerke, LAJ, de Graaf M, Wudneh T, Vijverberg J, Palstra AP. 2012a. Spawning migrations of the endemic Labeobarbus 
(Cyprinidae, Teleostei) species of Lake Tana, Ethiopia: status and threats. Journal of Fish Biology 81:750-765. DOI:10.1111/j.1095-8649.2012.03362.x.

Anteneh W, Dejen E, Getahun A. 2012b. Shesher and Welala floodplain wetlands (Lake Tana, Ethiopia): are they important breeding habitats for Clarias gariepinus and the migratory Labeobarbus fish species? The Scientific World Journal 2012: 1-10. DOI:10.1100/2012/298742.

Anteneh W, Getahun A, Dejen E, Vreven E. 2013a. Habitat Use and Downstream Migration of 0+ Juveniles of the Migratory Riverine Spawning Labeobarbus Spp. (Cypriniformes: Cyprinidae) of Lake Tana (Ethiopia). In Spawning Migration and Juvenile Habitat Use by Labeobarbus Spp. (Cyprinidae, Teleostei) of Lake Tana, Ethiopia, Anteneh W (ed.). Addis Ababa University, Addis Ababa, Ethiopia, pp 92-128.

Anteneh W, Getahun A, Dejen E. 2013b. Spawning migration of Lake Tana's Labeobarbus spp. (Teleostei: Cyprinidae) up the Ribb River, Ethiopia. African Journal of Aquatic Science, 38: 1 - 8. DOI:10.2989/16085914.2013.776942.

Anteneh W, Mengist M, Wondie A, Tewabe D, W/Kidan W, Assefa A, Engida W. 2014. Water hyacinth coverage survey report on Lake Tana, Technical Report Series 1. http://www.bdu.edu.et/sites/default/files/water hyacinth (accessed on May 23, 2016).

Anteneh W, Tewabe D, Assefa A, Zeleke A, Tenaw B, Wassie Y. 2015. Water hyacinth coverage survey report on Lake Tana Biosphere Reserve, Technical Report Series 2. http://www.bdu.edu.et/sites/default/files/water_hyacinth (accessed on May 23, 2016). Atnafu N, Dejen E, Vijverberg J. 2011. Assessment of the ecological status and threats of Welala and Shesher Wetlands, Lake Tana sub-basin (Ethiopia). Journal of Water Resource and Protection 3: 540-547. DOI:10.4236/jwarp.2011.37064. 
BoA (Bureau of Agriculture). 2010a. Directive for Providing Fishing License (DRAFT). Amhara National Regional Government, Bahir Dar, Ethiopia.

BoA (Bureau of Agriculture). 2010b. Directive for Assignment of Fish Inspectors (DRAFT). Amhara National Regional Government, Bahir Dar, Ethiopia.

de Graaf M, Dejen E, Sibbing FA, Osse JWM. 2000. Barbus tanapelagius, a new species from Lake Tana (Ethiopia): its morphology and ecology. Environmental Biology of Fishes 59:

1-9. DOI: $10.1023 / \mathrm{A}: 1007608208630$

de Graaf M. 2003. Lake Tana’s piscivorous Barbus (Cyprinidae, Ethiopia); ecology - evolution exploitation. de Graaf, PhD. thesis, Wageningen Institute of Animal Sciences, Wageningen University, The Netherlands, pp 249.

de Graaf M, Dejen E, Osse JWM, Sibbing FA. 2003. Ecological differentiation among the eight piscivores within the Barbus species flock (Pisces, Cyprinidae) of Lake Tana, Ethiopia. In Lake Tana's piscivorous Barbus (Cyprinidae, Ethiopia); ecology - evolution exploitation. de Graaf, Ph. D. thesis, Wageningen Institute of Animal Sciences, Wageningen University, The Netherlands, pp 51-81.

de Graaf M, Machiels MAM, Wudneh T, Sibbing FA. 2004. Declining stocks of Lake Tana's endemic Barbus species flock (Pisces; Cyprinidae): natural variation or human impact? Biological Conservation 116: 277-287. DOI:10.1016/S0006-3207(03)00198-8. de Graaf M, Nentwich D Osse JWM, Sibbing FA. 2005. Lacustrine spawning: is this a new reproductive strategy among 'Large' African Cyprinid fishes? Journal of Fish Biology 66: 1214-1236. DOI:10.1111/j.1095-8649.2005.00671.x.

de Graaf M, van Zwieten PAM, Machiels MAM, Lemma E, Wudneh T, Dejen E, Sibbing FA. 2006. Vulnerability to a small-scale commercial fishery of Lake Tana's (Ethiopia) 
endemic Labeobarbus compared with African catfish and Nile tilapia: An example of recruitment-overfishing? Fisheries Research 82: 304-18.

DOI:10.1016/j.fishres.2006.05.011.

Dejen E, Vijverberg J, Nagelkerke LAJ, Sibbing FA. 2004. Temporal and spatial distribution of microcrustacean zooplankton in relation to turbidity and other environmental factors in a large tropical lake (Lake Tana, Ethiopia). Hydrobiologia 513: 39-49.

DOI:10.1023/B:hydr.0000018163.60503.b8.

Dejen E, Vijverberg J, de Graaf M, Sibbing FA. 2006. Predicting and testing resource partitioning in a tropical fish assemblage of zooplanktivorous 'barbs': an ecomorphological approach. Journal of Fish Biology 69: 1356-1378. DOI:10.1111/j.1095-8649.2006.01197.x.

Dejen E, Vijverberg J, Nagelkerke, LAJ, Sibbing FA. 2009. Growth, biomass, and production of two small barbs (Barbus humilis and B. tanapelagius, Cyprinidae) and their role in the food web of Lake Tana (Ethiopia). Hydrobiologia 636: 89-100. DOI:10.1007/s10750009-9939-x.

Dejen E, Tewabe D, Mengist M, Chalachew A. 2015. Implementation plan for enforcement of the proclamation and regulation of Lake Tana Fish Resources. Report submitted to Amhara Region Livestock Development Agency, Bahir Dar, Ethiopia.

Downing, JA, Plante C, Lalonde S. 1990. Fish production correlated with primary productivity, not the morphoedaphic index. Canadian Journal of Fisheries and Aquatic Sciences 47: 1929-1936. 
Faife. 2003. Effect of Mesh Size and Twine Type on Gillnet Selectivity of Cod (Gadus morhua) in Icelandic Coastal Waters Institute for the Development of Small-Scale Fisheries. http://www.unuftp.is/static/fellows/document/jorge03prf.pdf (accessed on 1 Feb. 2016).

Federal Democratic Republic of Ethiopia.2003. The Federal Fish Resource Development and Utilization Proclamation 315/2003. Federal Democratic Republic of Ethiopia. Addis Ababa.

Gebremedhin S, Budusa M, Mingist M, Vijverberg J. 2013. Determining factors for fishers' income: The case of Lake Tana. International Journal of Current Research 5: 11821186.

Genet M. 2011. Environmental Degradation along the Southern shores of Lake Tana in the Twentieth Century. MSc Thesis, Bahir Dar University, Bahir Dar, Ethiopia.

Gessesse, B., Bewket, W., Bräuning, A. 2016. Determinants of farmers' tree-planting investment decisions as a degraded landscape management strategy in the central highlands of Ethiopia. Solid Earth 7: 639-650. DOI: http://dx.doi.org/10.5194/se-7-639-2016.

Getahun A, Dejen E, Anteneh W. 2008. Fishery studies of Ribb River, Lake Tana basin, Ethiopia. Final Report E1573, Vol. 2, Ethiopian Nile Irrigation and Drainage Project Coordination Office, Ministry of Water Resources, Ethiopia. http://projects.csg.uwaterloo.ca/inweh/display.php? ID=2085 (accessed on 26 Oct 2009).

Grobbelaar J.U. 1983. Availability to algae of $\mathrm{N}$ and $\mathrm{P}$ adsorbed on suspended solids in turbid waters of the Amazon Rivers. Archiv für Hydrobiologie 96: 302-316.

Heide Z. F. (2012). Feasibility Study for a Lake Tana Biosphere Reserve, Ethiopia. https://www.bfn.de/fileadmin/MDB/documents/service/Skript 317.pdf (accessed on June 7, 2014). 
Jul-Larsen E, Kolding J, Nielsen JR, Overa R, van Zwieten PAM. 2003. Management, comanagement or no management? Major dilemmas in southern African freshwater fisheries. Part 1: Synthesis Report. FAO Fisheries Technical Paper 426/1. FAO, Rome.

Lamb HF, Bates CR, Coombes PV, Marschall MH, Umer M, Davies SJ, Dejen E. 2007. Late Pleistocene dessication of Lake Tana, source of the Blue Nile. Quaternary Science Reviews 26: 287-299. DOI: 10.1016/j.quascirev.2006.11.020.

Mekonnen, M., S. D. Keesstra, J. E. Baartman, C. J. Ritsema, and A. M. Melesse. 2015. Evaluating Sediment Storage Dams: Structural Off-Site Sediment Trapping Measures in Northwest Ethiopia. Cuadernos De Investigacion Geografica 41: 7-22. doi:10.18172/cig.2643.

Melack JM. 1976. Primary productivity and fish yields in tropical lakes. Transactions of the American Fisheries Society 105: 575-580. DOI:10.1577/15488659(1976)105<575:PPAFYI>2.0.CO;2.

Mohammed B, de Graaf M, Nagelkerke LAJ, Mingist M, Anteneh W. 2012. Lake Tana's (Ethiopia) endemic Labeobarbus species flock; an uncertain future threatened by exploitation, land use and water resource developments. In Proceedings of the Ethiopian Fisheries and Aquatic Sciences Association (EFASA) 3:301-313.

Mohammed B, de Graaf M, Nagelkerke L, Mingist M, Anteneh W. 2013. Assessment of motorized commercial gillnet fishery of the three commercially important fishes in Lake Tana, Ethiopia. In Proceedings of the Ethiopian Fisheries and Aquatic Sciences Association (EFASA) 4: 75-106. 
Nagelkerke LAJ, Sibbing FA, van den Boogaart JGM, Lammens EHRR, Osse JWM. 1994. The barbs (Barbus spp.) of Lake Tana: a forgotten species flock? Environmental Biology of Fishes 39: 1-22. DOI:10.1007/BF00004751.

Nagelkerke LAJ, Mina MV, Wudneh T, Sibbing FA, Osse JWM. 1995. In Lake Tana, a unique fish fauna needs protection. Bioscience 45: 772-775. DOI: $10.2307 / 1312629$

Nagelkerke LAJ. 1997.The barbs of Lake Tana, Ethiopia: morphological diversity and its implications for taxonomy, trophic resource partitioning and fisheries. $\mathrm{Ph} \mathrm{D}$ thesis, Wageningen Institute of Animal Sciences, Wageningen University, The Netherlands: 296 pp.

Nagelkerke LAJ, Sibbing FA. 2000. The large barbs (Barbus spp., Cyprinidae, Teleostei) of Lake Tana (Ethiopia), with a description of a new species, Barbus osseensis. Netherlands Journal of Zoology 50: 179-214. DOI:10.1163/156854200X00072.

Nagelkerke LAJ, Leon-Kloosterziel KM, Megens HJ, de Graaf M, Diekmann OE, Sibbing FA. 2015. Shallow genetic divergence and species delineations in the endemic Labeobarbus species flock of Lake Tana, Ethiopia. Journal of Fish Biology. DOI:10.1111/jfb.12779.

Sibbing FA, Nagelkerke LAJ, Stet RJM, Osse JWM. 1998. Speciation of endemic Lake Tana barbs (Cyprinidae, Ethiopia) driven by trophic resource partitioning; a molecular and ecomorphological approach. Aquatic Ecology 32: 217-227.

DOI:10.1023/A:1009920522235.

Sibbing FA, Nagelkerke LAJ. 2001. Resource partitioning by Lake Tana barbs predicted from fish morphometrics and prey characteristics. Reviews in Fish Biology and Fisheries 10: 393-437.DOI:10.1023/A:1012270422092. 
Shimelis G, Srinivasan, R, Dargahi B, Assefa M . 2009. Spatial delineation of soil erosion vulnerability in the Lake Tana Basin, Ethiopia. Hydrological Processes 23: 3738-3750.

Sparre P, Venema SC. 1998. Introduction to tropical fish stock assessment. Part 1. Manual. FAO Fisheries Technical Paper 306.1, Rev. 2. FAO, Rome.

Stiassny MLJ, Getahun A. 2007. An overview of labeonin relationships and the phylogenetic placement of the Afro-Asian genus Garra Hamilton, 1922 (Teleostei: Cyprinidae), with the description of five new species of Garra from Ethiopia, and a key to all African species. Zoological Journal of the Linnean Society 150: 41-83.DOI: 10.1111/j.10963642.2007.00281.x.

Teshale B., 2003. Influence of sediment on physico-chemical properties of Lake Tana. Workshop 'Fish and Fisheries of Lake Tana: Management and conservation' 6-8 October 2003, Bahir Dar, Ethiopia.

Tewabe D. 2013. Status of Lake Tana commercial fishery, Ethiopia. ABC Research Alert 1: 116.

Vijverberg J, Sibbing FA, Dejen E. 2009. Lake Tana: Source of the Blue Nile. In The Nile, Origin, Environments, Limnology and Human Use, Dumont HJ (ed.). Springer, 163-191.

Vijverberg J, Dejen E, Getahun A, Nagelkerke LAJ. 2014. Zooplankton, fish communities and the role of planktivory in nine Ethiopian lakes. Hydrobiologia 722: 45-60. DOI:10.1007/s10750-013-1674-7.

Wondie A, Mengistu S, Vijverberg J, Dejen, E. 2007. Seasonal variation in primary production of a large high altitude tropical lake (Lake Tana, Ethiopia): effects of nutrient availability and water transparency. Aquatic Ecology 41: 195-207. DOI: $\underline{10.1007 / \mathrm{s} 10452-007-9080-8}$ 
Wondie A. 2010. Improving management of shoreline and riparian wetland ecosystems: the case of Lake Tana catchment. Ecohydrology \& Hydrobiology 10: 123-132. DOI: 10.2478/v10104-011-0017-4.

Wudneh T. 1998. Biology and management of fish stocks in Bahir Dar Gulf, Ethiopia. PhD thesis, Wageningen Institute of Animal Sciences, Wageningen University, The Netherlands, 143 pp.

Yitaferu B, Hurni H, Zeleke, G. 2004. Processes of land degradation in the Lake Tana Basin (LTB), Amhara Region, Ethiopia. Proceedings of the Symposium on Lake Tana watershed management. Bahir Dar University. September 24-25, 2004. Bahir Dar, Ethiopia, pp. 5-12. 
Table I. The fish species of Lake Tana, their taxonomic group, maximum length (Fork Length, cm), relative abundance, food and habitat. $*=$ endemic to Lake Tana catchment. Data from Nagelkerke \& Sibbing (2000), De Graaf et al. (2006), Dejen et al. (2006) and Vijverberg (unpublished). Habitats refer to: benthic $=$ predominantly present near the bottom in the lower part of the water column, pelagic $=$ predominantly present in upper part of the water column, littoral= inshore with or without macrophytes (0-4 $\mathrm{m}$ deep), sublittoral $=$ inshore without macrophytes $(4-8 \mathrm{~m}$ deep $)$, offshore $=$ open water $(8-14 \mathrm{~m}$ deep). (Modified after Vijverberg et al., 2009).

\begin{tabular}{|c|c|c|c|c|c|}
\hline Family & Species & $\begin{array}{l}\text { Max. } \\
\text { Length } \\
\text { (FL, } \\
\text { cm) }\end{array}$ & (3) & Food & Habitat \\
\hline Balitoridae & $\begin{array}{l}\text { Nemacheilus } \\
\text { abyssinicus }\end{array}$ & 3.6 & Rare & Algae & Benthic \\
\hline Cichlidae & O. niloticus & 40 & Common & $\begin{array}{l}\text { Macrophytes, } \\
\text { algae-detritus }\end{array}$ & $\begin{array}{l}\text { Pelagic, littoral, } \\
\text { sublittoral }\end{array}$ \\
\hline Clariidae & C. gariepinus & 70 & Common & $\begin{array}{l}\text { Fish, zooplankton, } \\
\text { benthic } \\
\text { invertebrates, algae }\end{array}$ & $\begin{array}{l}\text { Pelagic, littoral, } \\
\text { sublittoral }\end{array}$ \\
\hline \multirow[t]{3}{*}{ Cyprinidae } & B. tanapelagius* & 8.9 & Common & Zooplankton & $\begin{array}{l}\text { Pelagic, sublittoral, } \\
\text { offshore }\end{array}$ \\
\hline & B. humilis & 9.6 & Common & $\begin{array}{l}\text { Zooplankton, } \\
\text { benthic } \\
\text { invertebrates }\end{array}$ & $\begin{array}{l}\text { Benthic, littoral, } \\
\text { sublittoral }\end{array}$ \\
\hline & B. pleurogramma* & 4.0 & Common & Benthic & Benthic, wetlands, \\
\hline
\end{tabular}




\begin{tabular}{|c|c|c|c|c|}
\hline & & & invertebrates & flood planes \\
\hline G. dembecha & 17.0 & Common & Algae & Benthic \\
\hline G. dembeensis & 12.0 & Rare & Algae & Benthic \\
\hline G. regressus* & 13.5 & Common & Algae & Benthic \\
\hline G. tana* & 12.0 & Common & Algae & Benthic \\
\hline $\begin{array}{l}\text { Labeobarbus* } \\
\text { acutirostris }\end{array}$ & 41 & Common & Fish & Benthic, inshore \\
\hline L. brevicephalus* & 32 & Common & $\begin{array}{l}\text { Zooplankton, adult } \\
\text { insects }\end{array}$ & $\begin{array}{l}\text { Pelagic, sublittoral, } \\
\text { offshore }\end{array}$ \\
\hline L. crassibarbus* & 51 & Common & $\begin{array}{l}\text { Detritus, benthic } \\
\text { invertebrates }\end{array}$ & $\begin{array}{l}\text { Benthic, sublittoral, } \\
\text { offshore }\end{array}$ \\
\hline L. dainellii* & 49 & Occasional & Fish & Littoral \\
\hline L. gorgorensis* & 62 & Occasional & $\begin{array}{l}\text { Benthic } \\
\text { invertebrates, } \\
\text { bivalves }\end{array}$ & $\begin{array}{l}\text { Pelagic, littoral, } \\
\text { sublittoral, offshore }\end{array}$ \\
\hline L. gorguari* & 53 & Occasional & Fish & Littoral \\
\hline L. intermedius & 49 & Common & $\begin{array}{l}\text { Benthic } \\
\text { invertebrates, } \\
\text { gastropods, } \\
\text { macrophytes }\end{array}$ & Benthic, littoral \\
\hline L. longissimus* & 61 & Occasional & Fish & $\begin{array}{l}\text { Pelagic, littoral, } \\
\text { sublittoral }\end{array}$ \\
\hline L. macrophtalmus* & 43 & Common & $\begin{array}{l}\text { Fish, benthic } \\
\text { invertebrates, } \\
\text { detritus }\end{array}$ & $\begin{array}{l}\text { Pelagic, sublittoral, } \\
\text { offshore }\end{array}$ \\
\hline
\end{tabular}




\begin{tabular}{|c|c|c|c|c|}
\hline L. megastoma* & 82 & Common & Fish & $\begin{array}{l}\text { Pelagic, littoral, } \\
\text { sublittoral, offshore }\end{array}$ \\
\hline L. nedgia* & 71 & Common & $\begin{array}{l}\text { Insect larvae, } \\
\text { benthic } \\
\text { invertebrates }\end{array}$ & Benthic, littoral \\
\hline L. osseensis* & 29 & Rare & $\begin{array}{l}\text { Adult insects, } \\
\text { macrophytes }\end{array}$ & Littoral \\
\hline L. platydorsus* & 64 & Common & $\begin{array}{l}\text { Fish, insect larvae, } \\
\text { molluscs, detritus }\end{array}$ & $\begin{array}{l}\text { Benthic, sublittoral, } \\
\text { offshore }\end{array}$ \\
\hline L. surkis* & 43 & Occasional & $\begin{array}{l}\text { Macrophytes, algae, } \\
\text { benthic } \\
\text { invertebrates }\end{array}$ & Pelagic, sublittoral \\
\hline L. truttiformis* & 44 & Occasional & Fish & $\begin{array}{l}\text { Pelagic, sublittoral, } \\
\text { offshore }\end{array}$ \\
\hline L.tsanensis* & 39 & Common & $\begin{array}{l}\text { Insect larvae, } \\
\text { gastropods, benthic } \\
\text { invertebrates }\end{array}$ & $\begin{array}{l}\text { Benthic, sublittoral, } \\
\text { offshore }\end{array}$ \\
\hline Varicorhinus beso & 36 & Common & Benthic algae & Benthic, littoral \\
\hline
\end{tabular}


Table II. Average daily catch of $O$. niloticus, Labeobarbus spp. and C. gariepinus of the motorized commercial fishery in Lake Tana in 1991-1993 (Wudneh, 1998), 2001 (de Graaf et al., 2006) and 2010-2011 (Mohammed et al., 2012, 2013). Catch per unit effort in kg per boat trip (percentages between brackets).

\begin{tabular}{llll}
\hline Taxa & \multicolumn{2}{l}{ Average daily catch in kg per boat trip } \\
& (percentage) & \\
& & & \\
& $1991-1993$ & 2001 & $2010-2011$ \\
& & & \\
\hline O. niloticus & $47.8(27)$ & $75.6(54)$ & $42.2(75)$ \\
\hline Labeobarbus spp. & $62.0(35)$ & $28.0(20)$ & $6.1(11)$ \\
\hline C. gariepinus & $67.3(38)$ & $36.4(26)$ & $7.8(14)$ \\
\hline Total & & & \\
\hline
\end{tabular}




\section{List of Figures}

Figure 1. Overview of Lake Tana with its adjacent floodplain wetlands and dams under construction in the tributary rivers (modified after Heide, 2012).

Figure 2. Water hyacinth infestation status on the shore of Lake Tana in May 2015 (after Anteneh et al., 2015). 
Figure 1

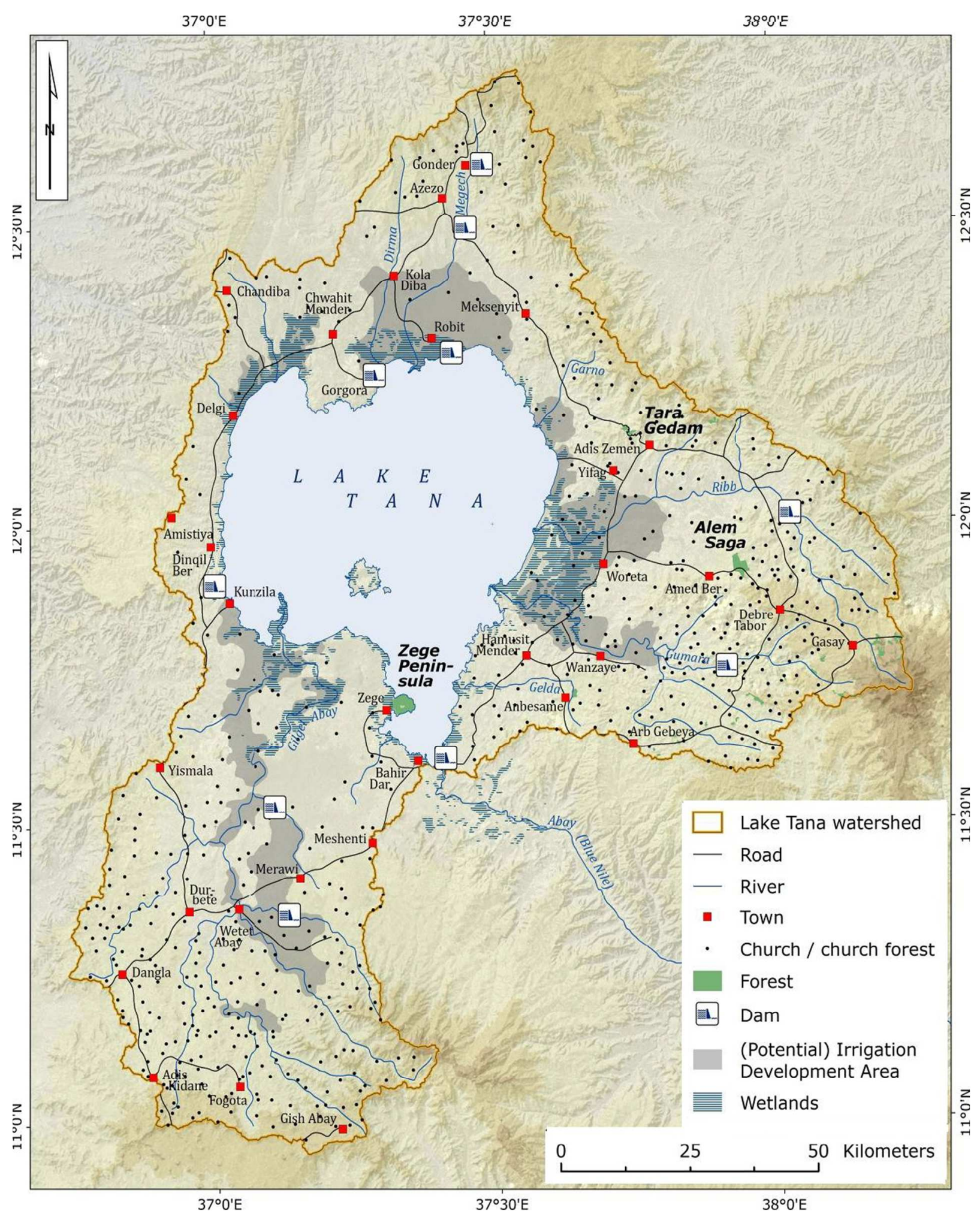


Figure 2.

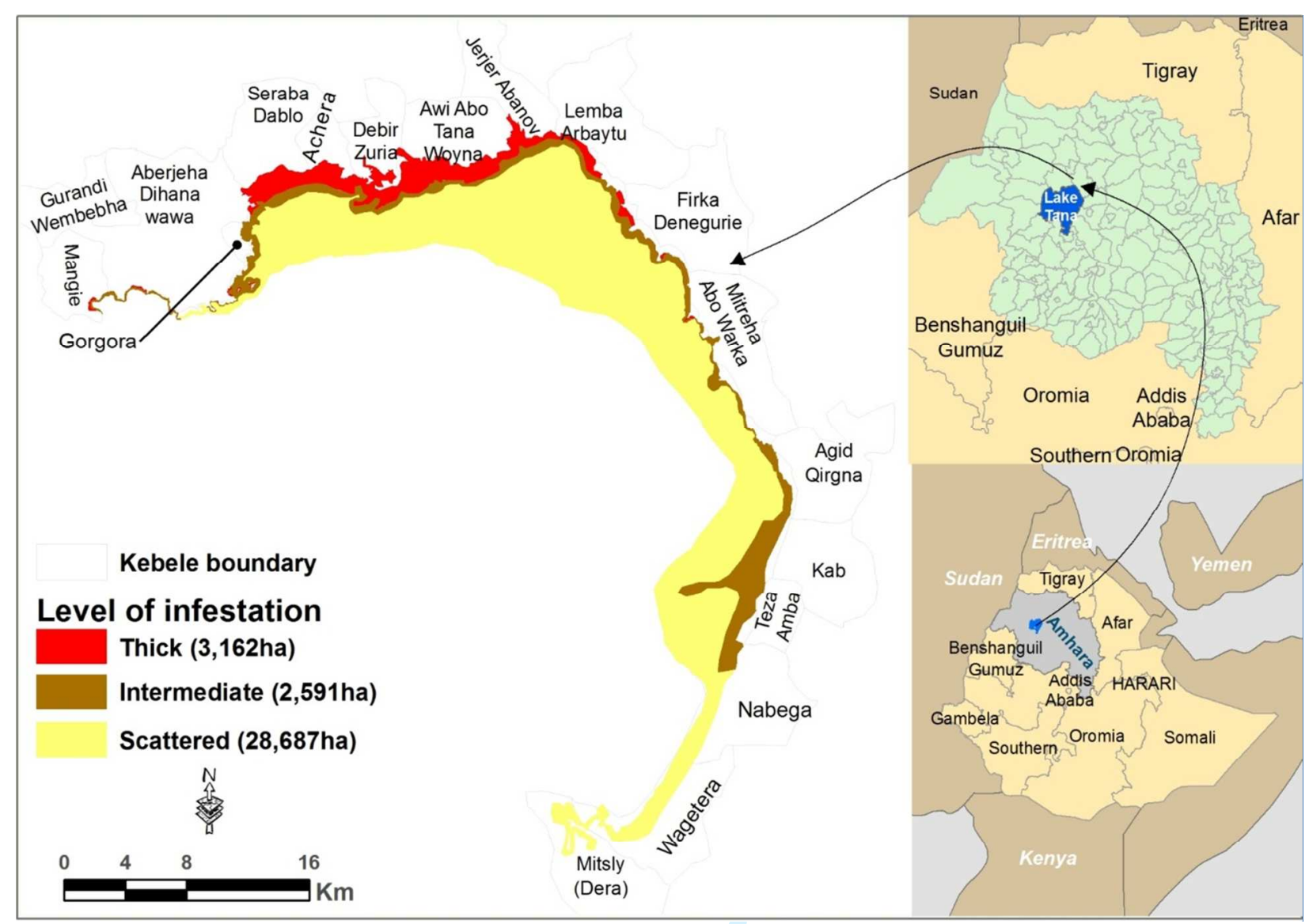

